\title{
THE OPERATIONAL HEDGING PROPERTIES OF INTANGIBLE ASSETS: THE CASE OF NON-VOLUNTARY FOREIGN ASSET SELLOFFS
}

\author{
John A. Doukas and Prasad Padmanabhan*
}

February 8, 2002

\begin{abstract}
In this paper we examine the valuation effects and long-term performance of U.S. multinational firms involved in forced transfers of their foreign operating assets during the 1965-1988 period. The evidence suggests that the operational hedging ability of the firm to address country risk (nationalization threats) is related to the level of its intangible assets. While it is well known that firms with high levels of intangible assets prefer foreign direct investment, our results show that intangible assets have hidden properties of protection against country risk as well. We document significantly negative abnormal returns only for divesting firms with low levels of intangible assets, but not for firms with high levels of intangible assets. In addition, we show that low (high) growth firms are involved in partial (complete) withdrawals, and show that the long-term economic performance of firms choosing the complete withdrawal strategy is better than those that opt to remain. We argue that management's attempt to maintain economic links in a hostile foreign environment can be attributed in part to the firm's low growth opportunities, performance, and lack of contingent plans to address country risk.
\end{abstract}

* Department of Finance, Stern School of Business, New York University, New York, NY 10012, School of Business and Public Administration, Old Dominion University, Norfolk, VA 23529-0218, and Distinguished Senior Research Fellow, Cardiff Business School, Cardiff, UK,e-mail:jdoukas@stern.nyu.edu, Tel: (212) 998-0432, and the Finance Department, San Diego State University, San Diego, CA 92182, respectively. We are grateful to Mark Flannery, Paul Seguin and Rene Stulz, and two anonymous referees for their helpful comments. 


\section{INTRODUCTION}

The period between 1960 and 1980 witnessed a spate of forced nationalizations of U.S. based multinationals. It is generally believed that this type of action by a host country represents the extreme form of country risk and can conceivably be considered as "bad news" for firms with operations in hostile host countries. Consequently, one should expect share prices of such firms to drop when such announcements are first made. Share price declines would be consistent with market's expectation of firm's performance deterioration following the forced foreign divestiture announcement. However, in this paper, we provide evidence that is not entirely consistent with this conjecture. Even though firms are unlikely to be subject to such a severe form of country risk today, firms continue to operate under host-country pressures and risks. For instance, the Asian financial crisis illustrated the potential instability of these countries. Therefore, studying the short- and longterm effects of forced selloffs associated with the nationalizations of the 1960-1980 period provide us with a unique opportunity to assess the role of corporate intangible assets as an "operational hedge" against varying levels of country risk, ranging from outright nationalizations to milder forms such as the recent Asian crisis.

While the internalization theory states that high levels of corporate intangible assets motivate foreign direct investment, we argue that they have operational hedging properties against country risk as well. Surprisingly, this attribute of intangible assets remains largely unexplored. Consistent with our view that intangible assets can act as an operational hedge against country risk, Langohr and Viallet (1986) show that shareholders of nationalized firms during the 1981-1982 nationalizations gained substantially from the compulsory transfer of shares to the French government. Interestingly, however, these gains were found to be firm specific. Langohr and Viallet (1986) estimate that nationalized firms received an average premium of about 20 percent, although the individual 
premiums for the 12 firms analyzed in this study ranged from - 3 percent to 44 percent. Although the determinants of the government-legislated takeover premiums were not the focus of this study, their results seem to suggest that the cross-sectional dispersion of premiums was related to unique characteristics of the nationalized firms. We argue that, among other factors, the dispersion in premiums can be related to the level of operational hedging properties (i.e., intangible assets) of nationalized firms.

In this paper, we examine the above contention using the announcement period price reactions of U.S. corporations subject to forced changes in their foreign ownership and control structure by host countries. ${ }^{1}$ Using data for the $1965-1988$ period, we show the existence of crosssectional dispersion in the valuation effects associated with the announcement of forced selloffs. This dispersion is inversely related to differences in the relative levels of intangible assets of the firm. Although the overall market reaction to such announcements is significantly negative, the negative reaction is observed only for firms with low levels of intangible assets. In addition, we also find a significant negative reaction for firms that opt to remain after being subject to external pressures, but not for those firms opting to completely withdraw from the hostile foreign country. Further examination reveals that firms that completely withdraw from the host country have significantly higher levels of intangible assets than firms opting to partially withdraw from the hostile environment. Hence, we argue that firms with high levels of intangibles are in a position to completely withdraw operations from such countries, with no concern for possible loss of revenues from such assets. We suggest that firms with high levels of intangible assets possess operational hedges that are capable of protecting shareholder value from the adversarial actions of host governments. Firms possessing high levels of intangibles can easily replace revenues lost in the

\footnotetext{
${ }^{1}$ Related literature on domestic voluntary selloffs include, for example, Alexander, Benson and Kampmeyer (1984), Jain (1985), Hite, Owers and Rogers (1987), and Lang, Poulsen and Stulz (1995) among others.
} 
hostile environment with revenues elsewhere and, therefore, protect shareholder wealth. On the other hand, firms with low levels of intangibles cannot easily replace lost revenues in hostile foreign environments. Such corporate weak trait should be reflected on firm's value. These firms, by selecting to remain in business-hostile environments, reveal their relative dependence on these foreign markets and lack of alternative business plans to cope with high country risk exposure. Furthermore, we show that the long-term financial performance of firms with high intangible assets marginally, but statistically insignificantly, improved relative to those with low intangible assets.

This paper is organized as follows. The next section describes the decision and the valuation effects of firms with high and low intangible assets. Section III reports the data and describes the methodology. In Section IV, we analyze the abnormal returns for firms with high and low levels of intangibles, and show that firms with high levels of intangibles have a higher probability of opting to completely withdraw from the hostile country, whereas firms with low levels of intangibles opt to remain. We also examine the market's reaction to country-specific news released prior to firmspecific withdrawal announcements, to check whether the market selectively anticipated the negative valuation effects for some firms (for example, those that completely withdraw at the firm specific announcement date), but not for others. This section concludes with the main results of the earnings performance analysis. Section V contains a summary of the results and our concluding remarks.

\section{VALUATION EFFECTS OF FOREIGN ASSET TRANSFERS}

\section{A. Intangible Assets and Relative Foreign Involvement}

When faced with a strategic threat from a hostile local government, firms with high levels of intangible assets may be easily able to seek replacements for lost revenues elsewhere. Consequently, firms with high levels of intangible assets possess operational hedges that are capable of protecting shareholder value from the adversarial actions of host governments. For 
instance, if firms possess relatively high levels of intangible assets, their operating losses in one country or region can easily be replaced by operating revenues elsewhere, with minimal depression in shareholder value. If a firm with extensive investments in intangibles is forced to withdraw from a hostile market, it may be better able to recoup its losses elsewhere. Other willing buyers provide a ready replacement market for the revenues lost in the hostile environment. For example, Gulf Resources ..."in view of the Mexican government's refusal to issue rulings that would enable the sale of (Gulf's assets) to take place,... the company couldn't permit the operations in Mexico to continue to affect profit and interfere with Gulf Resources' growth in the U.S..." (WSJ, 1 December, 1969). Here, the clear signal sent to shareholders is that a) the firm is not dependent on Mexican operations for sales and profits, and that b) it has growth opportunities elsewhere. Similarly, Bundy Corp's decision to pull out of South Africa based on the fact that they had other "growth oriented business opportunities elsewhere" (WSJ, 12 August 1988) implies that they could easily replace revenues lost in South Africa. On the other hand, firms with low levels of intangibles cannot easily replace lost revenues, and shareholders value such firms accordingly. Firms with low levels of intangible assets are strongly dependent on assets in place, and tend to lack contingent plans, global opportunities, or are faced with less favorable future cash flow opportunities to protect shareholder value. Such actions may also reveal the firm's poor quality management. For example, the subsidiary of General Electric "reluctantly" yielded to government Mexicanization pressures by selling $10 \%$ of its total assets in a public offering. (WSJ, 7 May, 1963, p. 8). The 'reluctance' indicates that the firm is dependent on assets in place in Mexico. Clearly, the signal sent to shareholders is that it is somewhat dependent on Mexican operations for revenues and profit. Similarly, Gulf Oil, in reaction to a takeover of Gulf's properties in Bolivia, indicated that they have been "... negotiating in good faith as recently as last Wednesday and we hope that negotiations may 
be resumed soon.." (WSJ, October 20, 1969). This suggests an undue dependence on assets in place. Atlantic Richfield said that ..."it had begun arbitration proceedings in an effort to protect and preserve oil holdings the Algerian government has declared forfeit.." (WSJ, May 14, 1969). Anaconda's chairman, in response to a desire expressed by the Chilean government for partial ownership of Anaconda's copper mines in Chile, indicated that the firm was prepared to discuss... "procedures to meet at least in part, the government's desire for greater participation.." (WSJ, May 22, 1969). These examples illustrate the relative weaknesses of firms' operating in a hostile environment. However, it is also possible that firms of either type may decide optimally, and choose to exit (or stay) if the benefits outweigh the costs. ${ }^{2}$ We argue that shareholders correctly identify high and low growth firms and value their shares accordingly. If this contention is correct, firms with high intangibles should experience a lesser reduction in firm value than firms with low intangibles. For such firms, management may feel compelled to retain a revenue base within the hostile environment. This would signal the firm's dependence on the foreign country and its limited growth opportunities outside elsewhere (low levels of intangible assets). Clearly, shareholders interpret this signal properly, and recognize the reduced ability of these firms to appropriate rents from their intangible assets in the foreign country.

\section{SAMPLE AND METHODOLOGY}

\section{A. Sample Selection}

The sample used in this study comprises 143 forced firm-specific foreign withdrawal announcements of U.S. multinational corporations that appeared in the Wall Street Journal (WSJ) during the 1965-1988 period. To the best of our knowledge, nationalizations or threats by host countries were extremely rare and infrequent after 1988. When a divestiture announcement was

\footnotetext{
${ }^{2}$ We thank an anonymous referee for this alternative suggestion.
} 
described in several articles of the WSJ, we used the earliest article to establish the announcement date. From this initial sample, we lost 29 observations because of contamination (two or more events at the same time), or lack of adequate daily returns data from CRSP tapes. After the initial screening, we were left with a total usable sample of 114 announcements. The sample also reflects diversity in terms of the nature of the forced divestiture. Based on keywords found in the WSJ announcement pages, approximately 43 of 114 sample cases were outright expropriations or nationalizations of firm assets in the foreign country, 21 of 114 cases represent instances where the U.S. firm is subject to strategic threats (imposition of local ownership laws, forcing firms to export more or import less, etc...), which does not culminate in outright expropriation, and 26 of 114 cases representing divestitures from South Africa, where the withdrawal was instigated by unpopular human rights policies favored by the foreign government, although strictly, the South African withdrawals cannot be considered as involuntary. ${ }^{34}$ The nature of the strategic threat for the remaining sample observations was unclear. Foreign host governments or government run corporations acquired $58.77 \%$ of the firms sold by U.S. MNCs over this 18 -year period. Private foreign firms (current managers) acquired about $8.77 \%(5.26 \%)$ of the firms sold by U.S. firms. Thus, only $14.03 \%$ of the target assets were sold to the private sector. Of the remaining, information on the buyer was unavailable in $24.46 \%$ of the cases, and $2.74 \%$ was sold to a combination of local private buyers, foreign buyers, and the local government.

\footnotetext{
${ }^{3}$ The 43 cases of outright expropriations cannot strictly be considered a signal for firm level strength. However, even if firms are forced to leave, it is our contention that strong firms (firms with high levels of intangibles) are batter able to survive an outright expulsion, whereas weaker firms do not. We show that investors are correctly able to gauge the strength of affected firms, and share prices react accordingly. We thank a referee for directing our attention to this important point.

${ }^{4}$ Firms may also choose to completely withdraw from foreign countries when residual stakes in the host country may harm business elsewhere due to blockage on government bids (Emhart Corp, from South Africa; 87/1/28), or because of shareholder complaints (Sara Lee Corp,86/10/31), or concern over loosing politically sensitive investors (Bell and Howell, 87/2/7). Since few such cases were identified in the sample, we do not explicitly control for such instances.
} 
Our sample contains only those firms whose common stocks are listed in the New York or American Stock Exchanges, and included in the Center for Research in Security Prices (CRSP) daily stock returns file. The sample was screened for contemporaneous announcements for a 5-day period prior to and after the announcement date. Firms with concurrent major corporate announcements (i.e., takeover activities, common stock repurchases, exchange offers, new security offerings and announcements of new contracts) for the ten-day period surrounding the announcement date were not included in the sample. This produced a net sample of 114 forced foreign divestitures. Table I shows the distribution of forced foreign withdrawal announcements by year and country over the $1965-1988$ period. The average number of foreign divestments per year is 6 with a maximum (minimum) of 13 (1). According to Panel B of Table I, the greatest incidence of foreign forced divestments occurred in South Africa (26), Chile (17) and Peru (14). The remaining announcements are evenly spread out among the other sample countries. Sample firms also reflect diversity in industry membership at the time of the divestiture announcement. 41 industries (4 digit SIC classification) are represented, with most cases in the Petroleum Refining industry (22 cases), followed by Aluminum Production and Financial Services (6 cases each) and Beverages (5 cases).

\section{[Insert Table I About Here]}

\section{B. Estimation of Abnormal Returns}

The event date of each forced foreign withdrawal is the date of the announcement in the WSJ. We examine returns over the two-day interval $(-1,0)$ using standard event study methodology described in detail in Brown and Warner (1985). Market model parameters are estimated using continuously compounded returns over the $(-125,-6)$ interval using the CRSP value weighted index as a proxy for the market return. Cumulative average abnormal returns are estimated over several intervals around the announcement day by averaging the abnormal returns for all firms in the final 
sample. Finally, the significance of estimated abnormal returns is obtained following Dodd and Warner (1983).

\section{EMPIRICAL RESULTS}

\section{A. Abnormal Returns and Intangible Assets}

Table II (first column in Panels A and B) presents the daily average abnormal returns (AAR) for sample firms around the forced withdrawal announcement $(-5,+5)$ date (Panel A), and the cumulative average abnormal returns (CAARs, Panel B) for selected intervals around the announcement date. For the entire sample, as shown in Panel A, the market's reaction is significantly negative. These results are broadly consistent with the rent-seeking hypothesis (Meyer, Milgrom and Roberts (1992)) that predicts a negative valuation effect on shareholders' wealth. Though this evidence demonstrates the relevance of the rent-seeking hypothesis, we have not yet controlled for the influence of other factors such as the firm's level of intangible assets.

The basic conjecture tested in this paper is that firms with low levels of intangibles experience a greater loss in firm value than firms with high levels of intangibles, and that shareholders can properly interpret the nature of a firm's intangibles when it faces a politically hostile environment. To investigate the validity of this conjecture, we distinguish between sample firms on the basis of the levels of intangible assets (i.e., entrepreneurship, managerial ability, R\&D and marketing capacity) by using the $R \& D$ plus advertising expenses to total assets ratio in the year prior to the foreign withdrawal announcement. A firm is classified into the high intangibles category if its $(\mathrm{R} \& \mathrm{D}+\mathrm{AE}$ (advertising) Expense)/Total Assets ratio in the year prior to the withdrawal is equal or greater than the industry median. ${ }^{5}$ If the firm's intangible assets ratio is less than the

\footnotetext{
${ }^{5}$ To classify firms into high and low intangible asset categories, the industry median is used since intangible levels is industry specific. Results are qualitative unchanged when the sample mean, industry mean and median were used to classify firms into high and low intangible assets categories. Complete results are available upon request from the authors.
} 
industry median, it is classified into the category of firms with low intangible assets. This classification procedure produced 49 firms with high intangibles and 57 firms with low intangible assets.

Table II presents results for the high and low intangible asset firms. AAR (CAAR) results are reported in Panel A (Panel B). ${ }^{6}$ Firms with low intangible assets incur, on average, a negative announcement day abnormal return of 0.6028 percent, whereas firms with high levels of intangibles experience smaller (and statistically insignificant) announcement day abnormal returns. This conclusion is valid over a wide range of windows in the $(-5,5)$ range, and in addition, the differences in valuation effects between the two groups are statistically significant. Hence, the evidence in Table II demonstrates that firms with low intangible assets experience the largest negative abnormal returns while firms with high intangible assets incur zero abnormal returns when they are forced to divest their foreign assets. ${ }^{7}$

These results suggest that firms with low levels of intangible assets tend to experience significantly negative abnormal returns when they are faced with a hostile political threat, whereas firms with high intangibles experience no such reaction. These findings demonstrate that shareholders are able to correctly read the relative strength of affected firms. In the next section, it is shown that there are other interesting differences between the two groups of firms. Firms with high intangibles tend to be those that generally choose to completely withdraw. In contrast, firms with

\footnotetext{
${ }^{6}$ One of the other variables, namely the degree of relative involvement, RFI, also seems to be a significant discriminator between the complete withdrawal and the partial withdrawal sub-samples. We did perform event study analysis for the two groups of firms with low and high degrees of involvement, and were able to confirm that high (low) involvement firms suffered no loss (high loss) in market value around the announcement period. However, since we used many different definitions of RFI because of data availability problems, we cannot place a high degree of confidence on these results.

7 This result seems to be consistent with Shapiro's [1989, pp. 383-84] conjecture that "becoming multinational is not a matter of choice but, rather, one of survival". For firms with low intangible assets their foreign operating exposure is critical to their survival, and explains why they realize substantial losses when they are forced to divest their operating assets abroad or why they might be interested in keeping some of their foreign operating exposure (i.e., partial selloffs).
} 
low intangibles generally opt to remain. It is argued here that these decisions made by firm management may be viewed as signals to shareholders that convey the nature of its intangibles. ${ }^{8}$

[Insert Table II About Here]

\section{B. Partial and Complete Withdrawals Sub-samples}

Based on arguments made earlier, we suggest that strong firms (proxied by their level of intangibles) are more likely to completely withdraw, if they face a choice in this regard. Weaker firms may opt to remain, and may only partially withdraw. To test this contention, we classified divestiture announcements into two sets: (a) partial and (b) complete withdrawals. Complete withdrawals involve sales of all foreign operating assets to private, local government, or government owned firms, and complete severance of any kind of economic links with the foreign host country after the forced transfer of assets. It is suggested that some firms may select this option when faced with hostile threats, and send a clear signal to shareholders that it can easily restore lost market share through operations elsewhere. ${ }^{9}$ Partial withdrawals are defined as forced sales of a division or other operating assets of the parent firm in the foreign country where the seller continues to maintain a reduced operating presence, either by residual ownership of assets, or by retention of technical/commercial links in the foreign country, in comparison to the pre-crisis period. We postulate that firms that choose to remain signal their weakness by indicating its strong dependence on assets in place, and/or its lack of contingent plans or decreased global opportunities. Such action

\footnotetext{
${ }^{8}$ One concern is whether the results are influenced by 'clustering effects'. i.e., the presence of multiple announcements within a country within the same $(-5,+5)$ interval. These could affect interpretation of the results because they violate the independence assumption. We checked the data for potential problems associated with clustering of data. Of the 114 cases, we found 23 cases where 2 or more firms events occurred on the same event date. These firms account for $2 \%$ of the sample. We reran the major cross sectional regressions without these 23 firms. The results show remarkable similarity both in terms of estimates, but also the $t$ statistics associated with these estimates. Complete results are available on request from the authors. We thank an anonymous referee for direction our attention to this issue.
}

${ }^{9}$ Alternatively, the decision to completely withdraw may also indicate a superior bargaining position relative to the foreign government. 
may also reveal the poor quality of firm management. Table III presents a small sample (15) of such announcements to illustrate the basis for classifying firms into the two categories. In general, the WSJ articles were used to identify key words in classifying the divestments as complete or partial withdrawals. $^{10}$

\section{[Insert Table III About Here]}

To examine whether the market's reaction to forced foreign withdrawals differs across the partial and complete withdrawal sub-samples, the event study analysis was repeated for both groups separately. From column 2 of Table IV (Panel A), it can be seen that U.S. multinational firms that partially withdraw from a hostile foreign country experience, on average, abnormal returns of 0.4208 percent $(-0.7112$ percent) at the announcement day (day -1$)$, indicating that stockholders of these firms realize a statistically significant loss. Similar conclusions hold true for the CAAR results presented in Panel B, particularly for the intervals $(-1,0)$ and $(-3,0) .{ }^{11}$

In contrast, there is no evidence of significant abnormal returns, on average, to complete withdrawal announcements. The results reported in Panels A (AARs) and B (CAARs) of Table IV show that complete withdrawal announcements do exert a negative but insignificant influence on the firm's market value. ${ }^{12}$ Moreover, as indicated in the last columns of Panels $\mathrm{A}$ and $\mathrm{B}$, there are statistically significant differences in announcement-period abnormal returns between the two sub-

\footnotetext{
${ }^{10}$ An alternate procedure to differentiate between complete and partial selloffs would be to examine whether the parent firm continues to have subsidiaries in the host country after the realized forced divestiture announcement. Unfortunately, such information was generally unavailable for the time period used in this study. Finally, firms involved in both partial and complete foreign divestitures in a given year have been excluded from our sample.

${ }^{11}$ Divestitures in the sample are not clustered in the complete or partial withdrawal sub-samples. For instance, 52.23\% and $40 \%$ of the expropriation cases are associated with complete and partial divestitures, respectively. The threat cases associated with complete and partial divestitures are $28.57 \%$ and $17.5 \%$, respectively.

12 The average announcement day returns are not the result of a few outliers. Panel A of Table IV illustrates that more than 65 percent of the partial selloffs and 56 percent of complete selloffs exhibit negative excess returns at the announcement day.
} 
samples. In addition, the negative abnormal returns for the overall sample are driven by the partial withdrawal group of firms.

These findings suggest that firms that completely withdraw from a hostile environment tend to exhibit no significant abnormal returns around the announcement period, whereas firms opting for the partial withdrawal alternative suffer significant negative abnormal returns. These findings seem to be similar to those reported for firms with high and low intangibles. The question, then, is whether firms that completely (partially) withdraw are associated with high (low) levels of intangibles.

\section{[Insert Table IV About Here]}

To address this issue, it may be useful to examine a broad range of financial characteristics for the two groups of firms, namely, those that completely withdraw, and those that opt to remain. A wide range of financial characteristics during the fiscal year preceding the divestiture announcement are reported in Table $\mathrm{V}$ and include information about firms' intangible assets, relative foreign involvement (investment) in the host country, extent of multinationality, and the financial strength of firms engaged in complete and partial foreign divestments. The two groups appear to have similar characteristics with respect to various measures of financial structure, multinationality and performance with the exception of intangible assets (R\&D plus advertising expenses) and relative involvement (investment) in the host country.

A preliminary indication of the validity of the proposition that firms with high intangibles are more likely to conduct complete withdrawals, can be found when Table V is examined. The last column confirms that firms involved in complete foreign withdrawals tend to have higher levels of intangible assets on average and lower relative involvement than firms involved in partial foreign withdrawals, and these differences (both the means and medians) are statistically significant at 
conventional levels. $^{13}$ This provides preliminary evidence of a strong link between high (low) intangible assets and complete (partial) withdrawals. Interestingly, the results also indicate that advertising intensive (consumption oriented) firms are more likely to engage in complete rather than partial withdrawals. Hence, it can be argued that firms with high marketing intangibles are likely to withdraw voluntarily in an attempt to protect firm value from interest groups' attacks (i.e., consumer boycotts). The possibility that firms may elect to withdraw from a country due to boycotting threats is more applicable in the case of South Africa than in other countries in our sample. ${ }^{14}$ In the next section, we examine whether these valuation effects found for the complete and partial withdrawal samples, are indeed due to differences in growth opportunities (i.e., level of intangible assets) between the two groups. ${ }^{15}$, after controlling for other potential factors that may account for these observed differences. These control factors are determined by past theory, and are also presented in the next section.

\section{[Insert Table V About Here]}

\section{Determinants of the Foreign Divestiture Wealth Effects}

Our analysis demonstrates a negative wealth effect associated with forced foreign withdrawal announcements by U.S. corporations when they possess low levels of intangibles and/or when they elect to remain in the hostile foreign country despite threats. In contrast, shareholders of U.S. MNCs that posses high levels of intangibles and/or completely withdraw from a foreign

\footnotetext{
${ }^{13}$ Moreover, further investigation of differences between the two types of foreign divestments with respect to financial strength, measured by Moody's bond rating, shows no discernible difference for firms announcing complete withdrawals compared to those announcing partial withdrawals. Fifty percent of partial foreign withdrawals and fiftyfive percent of complete withdrawals were made by firms rated Aa or higher.

${ }^{14}$ We would like to thank an anonymous referee, for this point.

${ }^{15}$ Alternatively, high growth firms (i.e., firms with high levels of intangibles) may have greater bargaining power with host countries than low growth firms, thereby generating higher prices (and less negative event period abnormal returns) for complete withdrawal.
} 
country (because the host government imposes too many restrictions on them or creates an environment that is not conducive to private business) do not experience any losses. To confirm that firms adopting the complete withdrawal option tend to be firms with high intangibles, we regress abnormal returns on these measures and several other control variables. ${ }^{16}$ First, we introduce the partial versus complete divestiture variable, PCD, to test whether the foreign divestiture wealth effect is dependent on the level of operating exposure in the foreign host country. This is a zero-one dummy variable that takes the value of 1 when a firm completely divests its assets in a foreign country and 0 when it undertakes partial divestment (i.e., maintains a fraction of its previous operating exposure in a foreign country). To capture the firm's degree of foreign involvement, DFI, we include the ratio of its foreign sales to total sales in the year preceding the withdrawal announcement. A forced foreign divestiture may be more harmful if the divesting firm has a smaller multinational network, since this decision may reduce its ability to benefit from the arbitrage of cross-border imperfections among countries and internalize the value of its information-based intangibles through its international network. ${ }^{17}$ Next, we proxy the divesting firm's intangible assets using its $\mathrm{R} \& \mathrm{D}$ plus advertising expenses to total assets ratio in the year preceding the announcement (INA). ${ }^{18}$ This variable is designed to explore the links between the information-based intangible assets of the divesting firm and abnormal returns. A forced foreign divestiture is expected to have no valuation effects if a divesting firm has a strong technical and managerial know-how (i.e.,

\footnotetext{
16 We use the standardized abnormal return in the interval $(-1,0)$ since most of the reaction to forced selloff announcements occurs during this period. Results are qualitatively unchanged when other broader intervals are used. These results are not reported here but are available upon request.

17 This draws on the evidence of Doukas and Travlos (1988) and Doukas (1995) that shows a positive relation between firm value and the multinational network of the firm.

${ }^{18}$ Results are qualitatively unchanged when other proxies for intangible assets, namely the Tobin's q ratio, average R\&D to total sales ratio over the three years preceding the announcement are used. Results are available on request from the authors.
} 
intangible assets) background. The firm's intangible assets may also be viewed as a measure of its managerial performance (Lang, Poulsen and Stulz (1995)). If investors recognize that the firm is well managed based on the depth of its intangible assets, they would not interpret the divestiture announcement as signaling negative news about the firm's performance. In contrast, for divesting firms with low intangible assets, the fact that they choose to undertake a partial, as opposed to a complete withdrawal, conveys to the market negative information about the performance of the firm prior to foreign withdrawal announcements. ${ }^{19} \mathrm{We}$ also introduce the relative foreign involvement variable (RFI) to account for differences in the degree of involvement in the hostile foreign country (see Table V) between the two subgroups. ${ }^{20}$

The rest of the independent variables are designed to control for effects that may potentially account for the observed findings. First, we proxy the size attribute using the total assets of the firm in the year prior to the announcement (TA), since control for size also controls for possible differences in terms of growth opportunities between small and larger firms. Forced foreign divestments by small firms with high growth opportunities may signal a downward revision in growth expectations, leading to a large negative share price reaction. Next, we include an indicator variable, PNP, to investigate whether the valuation effects are related to characteristics of the buyer (i.e., PNP $=1$ for a government buyer, 0 otherwise) can account for the valuation effects. Finally,

\footnotetext{
${ }^{19}$ Lang, Poulsen, and Stulz (1995) document evidence of poor performance prior to domestic sell-off announcement.

${ }^{20}$ The RFI measures the firm's involvement in the host country relative to the size of the parent firm. RFI is available for 57 of 114 cases (50\%), and is defined depending on data availability, as follows: Total assets in host country/ Global assets of firm (23 cases); Total sales in host country/Global sales of firm (19 cases); Total production in forced divestiture/Global production of firm (5 cases); and Price paid upon forced divestiture/Total assets of firm (10 cases). Host country, global production and price paid information were obtained from WSJ announcements while the rest of the information was extracted from annual COMPUSTAT tapes. The terms 'relative involvement' and 'relative investment stakes' are used interchangeably. Since different measures were used to proxy this variable, we were unable to place a great deal of credence on the results associated with this variable. For this same reason, we do not present the results associated with differences in abnormal returns between high and low RFI firms. Following a referee's suggestion, we examined the coefficient of correlation between the RFI and INA variables. The coefficient was 0.5076, $\mathrm{p}=.0007$. Despite this high correlation, both variables are significant (equation 7, Table VI). These results indicate that both attributes are important.
} 
four more indicator variables are used as control measures to investigate whether differences in sample characteristics are responsible for differences in abnormal returns. We introduce three dummy variables, respectively, EXP ( 1 = expropriation/confiscation, 0 otherwise), THR $(1=$ threat, 0 otherwise), and SAF (1 = indirect pressures to withdraw, 0 otherwise), to investigate whether the valuation effects were related to these factors. Finally, an OIL indicator variable $(1=$ oil sector, 0 otherwise) is introduced to examine if foreign divestiture returns are associated with the divestitures by 22 oil companies in our sample. ${ }^{21} 2223$

Table VI presents selected regression results to explain cross-sectional variation in excess returns associated with forced foreign divestiture announcements of U.S. MNCs. ${ }^{24}$ Tests of the regression residuals indicate no evidence of heteroskedasticity (White 1980). The first regression

21 The OIL variable was not significant. The specific results are:

$\operatorname{SCAR}(-1,0)=-0.2532+0.0298$ OIL, Adjusted $\mathrm{R}^{2}=-0.0094$, Number of observations $=107$, $\left(-2.60^{* *}\right) \quad(0.13)(\mathrm{t}$ values in parentheses).

${ }^{22}$ Following the referee's suggestion, we introduced additional country dummies for the only other countries with large cases, Chile (17 cases) and Peru (14 cases). These dummies were not significant. For Chile, the results were:

$\operatorname{SCAR}(-1,0)=-0.4732+0.112$ CHILE DUMMY + 0.4685 PCD;
$(-3.12)$
$(0.321)$
$(2.267)^{* *}(\mathrm{t}$ values in parentheses).

For Peru, the results were:

$\operatorname{SCAR}(-1,0)=-0.4088-0.3950$ PERU DUMMY + 0.4647 PCD;
$(-3.12)$
$(-1.34)$
$(2.234)^{* *}(\mathrm{t}$ values in parentheses)

These results indicate that the country dummies were not significant. In addition (results not reported), the significance of the PCD variables in the above regressions disappeared when placed alongside the INA variables. For the remaining countries, such analysis was not performed, since they were 3 or fewer cases per country, and the results would not be meaningful.

23 We also placed a natural resource dummy and reran the regressions. The results are as follows:

$\operatorname{SCAR}(-1,0)=-0.2094$ NRES + 0.4462 PCD, Adjusted R square $=0.0472$.

$$
\begin{array}{rlr}
(-0.988) & (2.252)^{* *} \\
\text { and, SCAR }(-1,0)=-0.4719 & -0.0849 \mathrm{NRES}+0.3220 \mathrm{PCD}+5.1692 \mathrm{INA} \text {, } \\
(-2.252)^{* *} & (-0.35) & (1.503)
\end{array}
$$

( $\mathrm{t}$ values in parentheses)

Adjusted R square $=0.0753$; These results indicate that the abnormal returns are not a natural resources phenomenon.

\footnotetext{
${ }^{24}$ Because of space limitations, only selected regression results where significance is obtained, or which are central to
} the study, are reported. Complete results are available from the authors. 
confirms that foreign divestiture returns are significantly higher for firms that pursue complete rather than partial divestments. However, the impact of the PCD dummy variable disappears after the introduction of the INA variable, (regressions 2 and 5). The INA variable is significant at conventional levels and consistent with the evidence reported in the event studies. The significant intangible assets variable implies that well managed firms with high growth opportunities are not expected to be adversely affected by forced foreign divestment decisions. Alternatively, these results imply that firms with high intangible assets are likely to have greater negotiating power and therefore incur lower losses than firms with low intangibles. Finally, with the exception of the SAF variable, none of the other independent variables were found significant. ${ }^{25} 26$

Overall, the regressions of Table VI suggest that, controlling for other seemingly relevant factors, divesting U.S. firms with low levels of intangibles experience the largest share price decreases following forced foreign withdrawal announcements. Clearly, such firms may have difficulty replacing revenues lost in the hostile foreign country through increased operations in other markets, and are therefore more likely to make an effort to maintain existing technical/commercial links with the host country. In contrast, firms with high intangible assets and a broad international

\footnotetext{
25 The significance of the SAF variable disappears after introduction of either the INA or the RFI variables, indicating that INA and/or RFI are responsible for the significance of the SAF variable. In addition, both the EXP and THR variables seem to be dominated by the INA and RFI variables, suggesting that the latter variables drive the abnormal returns. For EXP, the regression results are as follows:
}

$\operatorname{SCAR}(-1,0)=-0.3016-0.0628 \mathrm{EXP}+6.4446$ INA; $(-2.22)^{* *}(-0.304) \quad(2.434)^{* *}(\mathrm{t}$ values in parentheses).

For THR, the results are:

$\operatorname{SCAR}(-1,0)=-0.3689+0.1072 \mathrm{THR}+6.9082 \mathrm{INA}$; $(-2.84)^{* *}(0.483) \quad(2.866)^{* *}(\mathrm{t}$ values in parentheses).

These results suggest that the dominating factor driving abnormal returns is the INA variable.

${ }^{26}$ We also introduced another variable, REL to control for the degree of relatedness of the foreign subsidiary product category with the parent's principal product line. Based on industry descriptions provided by the 4 digit SIC codes, the sample observations were classified into related $(\mathrm{REL}=1)$ and unrelated divestment categories $(\mathrm{REL}=0)$. Description of business of the foreign divested units was obtained from the WSJ announcements, if available. Of the 114 announcements, 23 were classified as unrelated and 55 as related. The regression results show (not reported) that the coefficient of the REL variable is 0.0609 (with a t-value equal to 0.27 ) and statistically insignificant at any conventional level. Introducing the REL indicator variable in other key regressions did not materially alter the results reported in Table IX. 
operating network do not appear to be sensitive to forced foreign divestments probably because they are able to appropriate returns associated with their intangible assets elsewhere and/or because of their increased negotiating power generated from possession of high levels of intangible assets. ${ }^{27}$

$$
\text { [Insert Table VI About Here] }
$$

\section{Analysis of Country-specific News}

One potential problem with the evidence reported in the previous section is the possibility that the insignificant results reported for firms that possess high levels of intangibles (Table II and V) may be due, in part, to a possible market reaction before the official firm-specific announcement date. That is, for instance, at the time of a major political or country-specific announcement. To determine if this is the case, we first identified the announcement of major political events reported in the WSJ prior to the release of firm-specific announcements, and reran the event study regressions using country specific announcements. ${ }^{28} 29$

Event study results, untabulated, from the country-specific announcements suggest that stock-price reaction to country-specific announcements is remarkably similar to those observed for

27 At the suggestion of a referee, we conducted a logit regression which reinforces our main point. The results of a logit regression with the PCD dummy as the dependent variable, and INA as the independent variable provides us with the following results:

PCD vs INA: $\quad$ PCD $=\quad-0.4831+16.3407$ INA; Chi square $=6.715, \mathrm{p}=.0093$.

(p values) (.0997) (.0186)

Clearly, these results indicate that there is a higher probability that a firm with high intangibles will opt to completely withdraw. The significance level indicates that this result is not obtained by chance.

We also used other independent variables (RSIZE, DFI, TOTAL ASSETS), but because of lack of data availability on all independent variables, the results were not as strong, because of limited overall sample observations available for the logit regressions.

${ }^{28}$ Alternatively, the observation interval could be extended to include the major political event. Unfortunately, for these types of events the interval could be months or years. As a result, the change in firm value would be obscured by noise.

29 Some examples of major country specific news items are: Argentina, 71/03/23, Deltec International Ltd, "Country's army overthrew President Roberto M. Levingston in a bloodless coup".; Chile, 70/09/08, Bethlehem Steel, "U.S. copper mining firms seen resigned to Marxist's win, nationalization in Chile"; and South Africa, 85/02/05, Bell and Howell, "The mood in Johannesburg, South Africa, is blue because of a stepped up call around the world for the end of apartheid in the country". The complete list of country specific announcements is available on request from the authors. 
firm-specific announcements: the market reacts strongly negatively for firms undertaking partial withdrawals, but no significant market reaction is recorded for firms conducting complete withdrawals. These results are strongly consistent with those reported in Table II and V and suggest that rather than selectively anticipate for some firms, the market is remarkably consistent in its ability to anticipate the strength or relative involvement profile at the major country-specific announcement. Clearly, therefore, the lack of market reaction reported in Table III cannot be attributed to selective early anticipation for complete withdrawal firms on macro country-specific news. However, these results, coupled with the evidence reported in Table III suggest that while investors react to major country-specific news, their reaction is more pronounced at the time when firm-specific divestment announcements are made. It seems the latter announcements elicit greater market reaction because they reveal more accurately the vulnerability of the firm to national threats. In addition to examining the stock-price reaction to firm-specific news, we test for the market's response to country-specific news released for the country as a whole. The primary objective of this analysis is to investigate the relationship between market's reaction to country-specific and firmspecific (divestiture) announcements along with a set of control variables describing the type of divestment, firm's intangible assets and its relative investment exposure in the host country. Accordingly, we regress the dependent variable, $\operatorname{SCAR}_{\mathrm{i}}{ }^{\mathrm{F}}$ [the $(-1,0)$ CAAR at firm-specific announcement], against a set of independent variables, $\operatorname{SCAR}_{\mathrm{i}}{ }^{\mathrm{C}}$ (the corresponding $\mathrm{CAAR}$ at country-specific announcements), PCD, INA, and RFI (latter variables are defined earlier). If there is a country-specific response effect where firms with the greatest losses tend to experience the smallest subsequent abnormal returns around firm-specific divestment announcements, the correlation between $\mathrm{SCAR}_{\mathrm{i}}{ }^{\mathrm{F}}$ and $\mathrm{SCAR}_{\mathrm{i}}{ }^{\mathrm{C}}$ would be negative. However, if these variables are 
positively correlated, then any country-specific negative reaction is followed by a protracted period of relatively poor performance for the firm.

Table VII reports results of different versions of the regression model described above. Tests of the regression residuals indicate no evidence of heteroskedasticity (White 1980). The most interesting finding is that $\mathrm{SCAR}_{\mathrm{i}}^{\mathrm{F}}$ and $\mathrm{SCAR}_{\mathrm{i}}{ }^{\mathrm{C}}$ are positively and significantly correlated in all regressions. However, firm-specific divestment announcements also appear to play an important role in signaling valuable information about the divesting firm's investment opportunity set and bargaining power in the host country as indicated by the coefficient on the INA variable in all regressions. Consistent with our previous results, the PCD variable (complete-partial dummy), is positive and significant at conventional levels, indicating that average losses are significantly larger for firms engaged in partial foreign divestitures. The insignificance of the PCD variable in the presence of the INA variable, however, suggests that the losses from divestitures in foreign countries arise, not as a result of the partial divestments, from other factors such as the firm's low growth opportunities. The INA variable suggests that divesting firms with low growth opportunities are most likely to experience greater losses than firms with high growth opportunities. We show that this strength is related to the level of intangible assets and firm's multinational network.

[Insert Table VII About Here]

E. Earnings Performance Changes Before and After Forced Foreign Withdrawal

\section{Announcements}

In this subsection we examine the earnings performance of firms in our sample in the years before and after the forced foreign divestiture announcements. If our contention is correct, then firms with low (high) levels of intangible assets should exhibit poorer (better) earnings performance both prior to and immediately following the divestiture announcement. To test this conjecture, we 
study the parent firm's earnings performance two years before and after the divestiture announcement. Annual earnings per share (EPS), obtained from COMPUSTAT II files are used to measure divesting firms' earnings performance. The final sample consists of 100 firms two years prior to the divestment announcement and 77 firms two years after the announcement. These sample sizes reflect data availability on the COMPUSTAT II annual industrial files. Following Healy and Palepu (1988), the change in EPS for each firm over the (-2,2) year interval is expressed as a percentage of its stock price, $\mathrm{P}_{1}$. The standardized earnings change for firm $\mathrm{i}$ in year $\mathrm{t}$ is obtained as: $\Delta$ EPS $_{\text {it }},=\left(\mathrm{EPS}_{\mathrm{it}}-\mathrm{EPS}_{\mathrm{it}-1}\right) / \mathrm{P}_{\mathrm{i}} \mathrm{t}=-2, \ldots+2$, where $\mathrm{P}_{\mathrm{i}}$ is firm i's stock price one fiscal year prior to the foreign selloff announcement. EPS $_{\mathrm{it}}$ represents the annual earnings per share before extraordinary items and discontinued operations for firm $\mathrm{i}$ in year $\mathrm{t}$, estimated from: $\mathrm{EPS}_{\mathrm{it}}=\mathrm{IBED}_{\mathrm{it}} / \mathrm{SSHARE}_{\text {it }} *$ FACTOR ${ }_{\text {it }}$ ) where $\mathrm{IBED}_{\mathrm{it}}$ represents the income before extraordinary items and discontinued operations, $\mathrm{SHARE}_{\mathrm{it}}$ measures the number of outstanding common shares, and FACTOR $\mathrm{it}_{\mathrm{it}}$ is the cumulative adjustment factor for firm $\mathrm{i}$ in year $\mathrm{t}^{30}$ To control for possible industry effects, EPS changes were adjusted for the industry median EPS change. The industry-adjusted standardized EPS changes for each sample firm are estimated as the difference between the standardized $\Delta$ EPS for each sample firm and the median standardized $\triangle$ EPS for firms in the same three-digit SIC code industry. ${ }^{31}$

Standardized earnings changes for parent firms engaged in forced foreign withdrawals are documented in Table VIII for the entire sample and several sub-samples over the $(-2,2)$ years-period surrounding the divestiture date. Table VIII reports raw, industry-adjusted, mean and median values for firms with high (low) levels of intangible assets. In general, for the entire sample, there appears

\footnotetext{
${ }^{30}$ The number of outstanding common shares (SHARE) was multiplied by the adjustment factor to adjust annual EPS data for all stock splits and stock dividends.
} 
to be a decline in earnings performance both prior to and after the announcement. However, the sub-sample results provide some interesting observations. In particular, for firms with high levels of intangible assets, although the median raw returns are uniformly higher both prior to and after the announcement (Panel B), the industry adjusted median returns are not significantly different from zero. In contrast, the earnings performance results reported for firms with low intangible assets (Panel C), suggest that there is some evidence that these firms are poor performers relative to he industry median both prior to and after the announcement. ${ }^{32}$ Since these findings are not statistically significant, we conclude that we are unable to unequivocally show that low intangible firms exhibit poorer earnings performance. This is left as a puzzle for future research.

\section{[Insert Table VIII About Here]}

\section{F. Robustness: Diagnostic Checks and Alternative Interpretations}

We have interpreted the evidence in this paper along the idea that intangible assets have operational hedging properties against country risk (i.e., protect shareholder value from political threats). Namely, the operational hedging attribute of intangible assets implies that corporate cash flows are less likely to be location dependent. However, two additional questions emerge: (i) are our empirical findings sensitive to clustering effects within a given industry or country? That is, are the results driven by a particular industry (for instance, the resource industry), or multiple announcements within a country?, and (ii) are the results consistent with alternative interpretations? As far as the first point is concerned, it may be argued that the results are driven by industries with high intangible assets like chemical firms, utilities, etc. By measuring intangibles as deviations from industry median, we can rule out this factor. Similarly, the results are unlikely to be

${ }^{31}$ Kaplan (1989), Blackwell, Marr, and Spivey (1990), and Healy and Palepu (1990) use the industry median to estimate industry adjusted changes. 
affected by clustering of political threats within a country. In our sample, three countries, namely, South Africa, Chile, and Peru account for $22.80 \%, 14.91 \%$ and $12.28 \%$ of the sample cases, respectively. Diagnostic checks performed with and without firms with operating exposure in these countries suggest country clustering effects do not alter the major conclusion that the different share price reactions are related to the level of intangibles, and not to country clustering effects.

Regarding the second point, it is possible that alternative explanations can account for the observed findings. For instance, our results are also consistent with the bargaining power view in the sense that intangible intensive firms are more likely to take a stronger stance against political threats and withdraw their foreign operations without any adverse valuation effects. The evidence, particularly for firms operating in South Africa, may be due to a "protection from boycott" effect. That is, advertising intensive (and marketing oriented) firms may be more likely to conduct "complete asset transfers" since such withdrawals may add firm value by impeding consumer boycotts. 33

These alternative explanations are not inconsistent with the operational hedge view we have proposed in this paper. Prior literature has used this proxy to capture a lot of different attributes (technology, managerial performance, growth opportunities etc..).The intangible measure can also accommodate the bargaining power and protection from boycott views. ${ }^{34}$ We have argued that firms with high intangible assets are strong, but we do not specify the sources of this strength. The literature has documented a strong positive correlation between intangible assets and Tobin's Q.

\footnotetext{
32 These conclusions generally hold even after controlling for other extraneous factors using "matched firm" criteria based on total assets in the year prior to the divestment. These results are not reported here but are available upon request.

${ }_{33}$ Cases where firms conduct complete withdrawals to prevent consumer boycotts may be considered as voluntary. However, we include this sample set here because the primary motivation for such withdrawals was due to local governmental actions that limit the strategic autonomy of operating firms. Thus, such cases could be viewed as involuntary.
} 
The Q ratio can capture a wide range of attributes related to managerial strength, including superior bargaining or negotiating power, and superior performance. Hence, our operational hedge measure is broad enough to accommodate other aspects of hedging such as bargaining power and, therefore, explain why firms conduct complete withdrawals motivated by strength elsewhere within their system. However, if these threats can cause a system-wide loss of revenue, as may be the case when firms decide to remain in South Africa, then "pulling out" may be viewed as good news regardless of the degree of the operational hedging intensity of the firm. The question, then remains as to why less advertising intensive firms should suffer a price decline from complete withdrawals. ${ }^{35}$

We contend that the complete withdrawal of such firms is not driven by operational strength factors, but by concerns of system-wide loss of revenues. It is possible that less-advertising intensive firms have limited options to regain lost revenues elsewhere than other more advertisingintensive firms. Examination of the South Africa sub-sample revealed that only 4 out of 17 firms that completely withdrew were less advertising-intensive in comparison to the industry median. The detailed analysis of such cases is left for future research. On balance, however, we find strong evidence in support of our contention that intangible assets possess valuable operational hedging properties as well.

\section{CONCLUSIONS}

This study investigates the short- and long- term performance of U.S. multinational firms in response to forced transfer of their foreign operating assets to private and non-private foreign (host country) buyers over the 1965-1988 period. We document a strong negative reaction to such announcements during an 11-day window surrounding the announcement date. The most interesting result is that the market reacts significantly negatively only for firms with low intangible assets

\footnotetext{
${ }^{34}$ Doukas, et. al. (1999), also illustrate that the nature of intangible assets plays an important role for explaining in the the shape of firm's expansion and its multinational network structure as well.
} 
and/or those that choose to maintain an operating link in the hostile foreign country (i.e., firms that elect the partial withdrawal strategy), but not for firms with high intangibles or opting for the complete withdrawal strategy. A closer examination reveals that firms that partially withdraw tend to possess low levels of intangible assets. Cross-section regression results on two-day abnormal returns suggest that this explanation dominates other explanations captured by selected control variables. Consistent with the short-term results, post-event performance analysis reveals that firms with high levels of intangibles tend to possess superior (but statistically insignificant) earnings (raw, industry median adjusted, and matched firm adjusted) when compared to low intangibles firms. These findings, while consistent with the rent-seeking hypothesis, show that high levels of corporate intangible assets can act as an operational hedge against nationalization, nationalization threats by hostile foreign governments, and country risk in general. While it is well known that firms with high levels of intangible assets prefer foreign direct investment, our results show that intangible assets have hidden properties of protection against country risk. Firms with low levels of intangible assets, however, should consider other forms of foreign involvement (i.e., joint venture) because of the limited hedging power of their intangible assets against country risk. In addition, our findings provide one set of rationalizations for the cross sectional dispersions in takeover premiums reported in the Langohr and Viallet (1986) study of French nationalizations. Future research may be directed at investigating whether firms with different levels of intangible assets were similarly protected during the recent Asian economic crisis.

\footnotetext{
${ }^{35}$ We thank an anonymous referee for this important point.
} 


\section{REFERENCES}

Alexander, G., P. Benson, and J. Kampmeyer. 1984. Investigating the valuation effects of announcements of voluntary corporate selloffs. Journal of Finance, June: 503-17.

Asquith, P., and D. Mullins. 1986. Equity issues and stock price dilution. Journal of Financial Economics. 15: 61-89.

Blackwell, D., W. Marr, and M. Spivey. 1990. Plant-closing decisions and the market value of the firm. Journal of Financial Economics. 26: 277-88.

Buchanan, J. M. 1980. Rent seeking and profit seeking. In J. M. Buchanan, R. D. Tollison and G. Tullock, editors, Toward a Theory of the Rent-seeking Society. College Station, Texas: Texas A\&M Press.

Dodd, P. and J. Warner. 1983. On corporate governance: A study of proxy contexts. Journal of Financial Economics. April: 401- 38.

Doukas, J., 1995, Overinvestment, Tobin's q and gains from foreign acquisitions, Journal of Banking and Finance 19, 1285-1303.

Doukas, J., C Pantzalis, and S. Kim, 1999, Intangible assets and the network structure of MNCs, Journal of International Financial Management and Accounting 10, 1-19.

Doukas, J. and N. Travlos, 1988, The effect of corporate multinationalism on shareholders wealth: Evidence from international acquisitions, Journal of Finance 43, 1161-1175.

Eckbo, B. E.. 1986. Informational asymmetrics and valuation effects of corporate debt offerings. Journal of Financial Economics.15: 119-51.

Healy, P. and K. Palepu. 1990. Earnings and risk changes surrounding primary stock offers. Journal of Accounting Research. Spring: 25-48.

Hite, G. L., J. E. Owers, and R. C. Rogers. 1987. The market for interfirm assets sales: partial selloffs and total liquidation. Journal of Financial Economics.18: 229-52.

Jain, P. 1985. The effects of voluntary selloff announcements on shareholder wealth. Journal of Finance. March: 209-24.

Kaplan, S. 1989. The effects of management buyouts on operating performance and value. Journal of Financial Economics. 24: 217-54.

Klein, A. 1986. The timing and substance of divestiture announcements: individual, simultaneous and cumulative effects. Journal of Finance. July: 685-96. 
Lang, L., A. Poulsen, and R. Stulz 1995. Asset sales, firm performance, and the agency costs of managerial discretion. Journal of Financial Economics, January 1995: 3-38.

Langohr, H. M., and C. J. Viallet. 1986. Compensation and wealth transfers in the French nationalizations: 1981-1982. Journal of Financial Economics. 17: 273-312.

Masulis, R. W., and A. Korwar. 1986. Seasoned equity offerings: an empirical investigation. Journal of Financial Economics. 15: 91-118.

Meyer, M., P. Milgrom and J. Roberts. 1992. Organizational prospects, influence costs and ownership changes. Journal of Economics and Management Strategy. 9-35.

Milgrom, P. 1988. Employment contacts, influence activities, and efficient organization design. Journal of Political Economy. 42-60.

Mikkelson, W. H., and M. M. Partch. 1986. Valuation effects of security offerings and the issuance process. Journal of Financial Economics. 1531-60.

Porter, M. 1976. Please note nearest exit: exit barriers and planning. California Management Review. March, 19: 2-23.

Smith, Jr., C. W. and R. W. Watts. 1992. The investment opportunity set and corporate financing, dividend and compensation policies. Journal of Financial Economics, Vol. 32, December No.3 : 263-292..

White, H. 1980. A heteroskedasticity. consistent covariance matrix estimator and a direct test for heteroskedasticity. Econometrica. 48: 817-38. 
Table I

Distribution of Foreign Asset Transfer Announcements by Year and Country, 1965-1988

\begin{tabular}{|c|c|c|c|c|c|}
\hline \multicolumn{3}{|c|}{$\begin{array}{l}\text { A. Annual Distribution of } \\
\text { Foreign Divestments }\end{array}$} & \multicolumn{3}{|c|}{$\begin{array}{l}\text { B. Geographical Distribution of } \\
\text { Foreign Divestments }\end{array}$} \\
\hline Year & Frequency & $\%$ & Country & Frequency & $\%$ \\
\hline 1965 & 3 & 2.63 & Algeria & 5 & 4.38 \\
\hline 1967 & 4 & 3.50 & Argentina & 2 & 1.75 \\
\hline 1968 & 2 & 1.75 & Bahrain & 3 & 2.63 \\
\hline 1969 & 10 & 8.75 & Bolivia & 2 & 1.75 \\
\hline 1970 & 11 & 9.64 & Canada & 1 & 0.87 \\
\hline 1971 & 12 & 10.52 & Chile & 17 & 14.91 \\
\hline 1972 & 6 & 5.26 & Ecuador & 3 & 2.63 \\
\hline 1973 & 3 & 2.63 & Ethiopia & 1 & 0.87 \\
\hline 1974 & 13 & 11.40 & Guyana & 1 & 0.87 \\
\hline 1975 & 10 & 8.87 & Indonesia & 3 & 2.63 \\
\hline 1976 & 3 & 2.63 & India & 3 & 2.63 \\
\hline 1977 & 5 & 438 & Iraq & 2 & 1.75 \\
\hline 1978 & 3 & 2.63 & Italy & 1 & 0.87 \\
\hline 1979 & 3 & 2.63 & Jamaica & 3 & 2.63 \\
\hline 1983 & 1 & 087 & Libya & 3 & 2.63 \\
\hline 1986 & 13 & 11.40 & Liberia & 2 & 1.75 \\
\hline 1987 & 11 & 9.64 & Mexico & 3 & 2.63 \\
\hline 1988 & 1 & 0.87 & Morocco & 1 & 0.87 \\
\hline $1965-1988$ & 114 & & Namibia & 2 & 1.75 \\
\hline & & & Nicaragua & 1 & 0.87 \\
\hline & & & Nigeria & 3 & 2.63 \\
\hline & & & Panama & 2 & 1.75 \\
\hline & & & Peru & 14 & 12.28 \\
\hline & & & Puerto Rico & 1 & 0.87 \\
\hline & & & South Africa & 26 & 22.80 \\
\hline & & & Uganda & 1 & 0.87 \\
\hline & & & Venezuela & 6 & 5.26 \\
\hline & & & Zambia & 2 & 1.75 \\
\hline
\end{tabular}




\section{Table II}

A. Daily Average Abnormal Returns (AARS) for the samples of the 107 Forced Foreign Asset Transfers of U.S. MNCs, 43 Partial Asset Transfers, 41 Complete Asset Transfers, the \% of Positive AARs for all three Samples, the Z-values for the Daily Mean Difference of AARs between Firms with Low and High Intangible Assets for the Event Period -5 Trading Days to +5 Trading Days Around the Initial Announcement (Day Zero) of Foreign Asset Transfers; 1965-1988

\begin{tabular}{|c|c|c|c|c|c|c|c|}
\hline \multirow{2}{*}{ Day } & \multicolumn{3}{|c|}{ Average Abnormal Returns, AAR, (\%) } & \multicolumn{3}{|c|}{ Positive AAR (\%) } & \multirow{2}{*}{$\begin{array}{c}\text { Z-difference } \\
\text { AAR }_{\text {Low }}-\mathbf{A A R}_{\text {High }}\end{array}$} \\
\hline & $\begin{array}{c}\text { Total } \\
\text { Sample } \\
(\mathbf{N}=107)\end{array}$ & $\begin{array}{l}\text { Firms with Low } \\
\text { Intangible Assets } \\
\quad(\mathbf{N}=57)\end{array}$ & $\begin{array}{l}\text { Firms with High } \\
\text { Intangible Assets } \\
\quad(\mathrm{N}=49)\end{array}$ & $\begin{array}{c}\text { Total } \\
\text { Sample }\end{array}$ & $\begin{array}{l}\text { Firms with Low } \\
\text { Intangible Assets }\end{array}$ & $\begin{array}{c}\text { Firms with High } \\
\text { Intangible } \\
\text { Assets }\end{array}$ & \\
\hline-5 & 0.0853 & 0.5522 & $-0.4120 *$ & 52.3 & 64.9 & 39.2 & $2.54 * *$ \\
\hline-4 & 0.1806 & 0.1224 & 0.3272 & 48.6 & 45.6 & 52.9 & -0.09 \\
\hline-3 & -0.2472 & -0.3889 & -0.0328 & 41.1 & 42.1 & 45.1 & -0.07 \\
\hline-2 & -0.0130 & -0.1044 & -0.0482 & 45.8 & 50.9 & 39.2 & -0.09 \\
\hline-1 & -0.3685 & -0.4570 & -0.1083 & 46.7 & 45.6 & 51.0 & -0.49 \\
\hline 0 & $-0.2998 * *$ & $-0.6028 * *$ & 0.0008 & 38.3 & 31.6 & 43.1 & $-2.27 * *$ \\
\hline 1 & -0.2026 & -0.1213 & -0.3305 & 51.4 & 52.6 & 49.0 & 0.91 \\
\hline 2 & 0.3783 & $0.7555^{*}$ & -0.0371 & 53.3 & 54.4 & 54.9 & 1.10 \\
\hline 3 & 0.0830 & 0.0200 & 0.2091 & 45.8 & 45.6 & 51.0 & -0.98 \\
\hline 4 & -0.1405 & $-0.3897 * *$ & 0.1297 & 43.9 & 35.1 & 52.9 & $-2.02 * *$ \\
\hline 5 & -0.2130 & -0.1668 & -0.2455 & 48.6 & 43.9 & 52.9 & 0.76 \\
\hline
\end{tabular}

B. Cumulative Average Abnormal Returns (CAARs) for the Samples of the 107 Forced Foreign Divestitures of U.S. MNCs, 43 Partial Divestments (selloffs), 41 Complete Divestments (selloffs), the Z-values for the Mean Difference of CAARs Between Firms with Low and High Intangibles for Several Window Intervals Around the Two-Day Announcement Period (-1,0) of Foreign Divestitures; $1965-1988$

\begin{tabular}{|c|c|c|c|c|}
\hline \multirow[b]{2}{*}{$\begin{array}{l}\text { Trading } \\
\text { Interval }\end{array}$} & \multicolumn{3}{|c|}{ Cumulative Average Abnormal Returns, AAR, (\%) } & \multirow[b]{2}{*}{$\begin{array}{c}\text { Z-difference } \\
\text { CAAR }_{\text {Low }}-\mathbf{C A A R}_{\text {High }}\end{array}$} \\
\hline & $\begin{array}{l}\text { Total Sample } \\
(\mathrm{N}=107)\end{array}$ & $\begin{array}{l}\text { Firms with Low Levels of Intangible } \\
\text { Assets ( } N=57)\end{array}$ & $\begin{array}{l}\text { Firms with High Levels of } \\
\text { Intangibles } \\
(\mathrm{N}=49)\end{array}$ & \\
\hline$[-5$ to 5$]$ & -0.7495 & -0.7808 & -0.5475 & -0.76 \\
\hline$[-3$ to 0$]$ & $-0.9284 * *$ & $-1.5330 * * *$ & -0.1885 & -1.46 \\
\hline$[-2$ to 2$]$ & -0.5056 & -0.5299 & -0.5233 & -0.38 \\
\hline$[-2$ to 0$]$ & $-0.6812 * *$ & $-1.1641 * * *$ & -0.1557 & $-1.65^{*}$ \\
\hline$[-1$ to 0$]$ & $-0.6683 * *$ & $-1.0597 * * *$ & -0.1075 & $-1.96 * *$ \\
\hline$[-1$ to 1$]$ & $-0.8709 * *$ & $-1.1810 * *$ & -0.4380 & -1.07 \\
\hline [0 to 5$]$ & -0.3947 & $-0.5051 *$ & -0.2734 & -1.45 \\
\hline
\end{tabular}

Notes: (1) Day 0 is the first announcement date associated with the selloff as reported in the Wall Street Journal.

(2) A sample firm is classified into the low intangible assets category if the (RND + ADV Exp)/Total Assets rates in the year prior to the selloff was less than the industry median, and into the 'high' category otherwise. (3) '***' ('**', '*') denotes significance at the $\leq 0.01(0.05,0.10)$ level. 


\section{Table III}

\section{Selected Sample of Partial and Complete Foreign Asset Transfers}

\begin{tabular}{|c|c|c|c|c|}
\hline Parent Firm & $\begin{array}{l}\text { Wall Street Journal } \\
\text { Event Date } \\
\text { (year/month/day) }\end{array}$ & $\begin{array}{l}\text { Target } \\
\text { Country }\end{array}$ & Wall Street Journal Quotation & $\begin{array}{l}\text { Classification Code: } \\
\text { C = Complete Asset } \\
\text { Transfer; P = Partial } \\
\text { Asset Transfer }\end{array}$ \\
\hline Dun and Bradstreet & $86 / 12 / 10$ & South Africa & $\begin{array}{l}\text { "End all its business in South Africa. Dun and } \\
\text { Bradstreet isn't taking a half hearted approach } \\
\text { because it avoided signing licensing agreements for } \\
\text { its products or maintain other ties..." }\end{array}$ & $\mathrm{C}$ \\
\hline Coca Cola & $86 / 09 / 18$ & South Africa & $\begin{array}{l}\text { "Coca Cola will arrange for concentrate to come } \\
\text { from another source... The decision to divest was } \\
\text { easier on coke than for other companies--it won't } \\
\text { lose any money...its products will still be sold } \\
\text { through independent bottlers in South Africa.." }\end{array}$ & $\mathrm{P}$ \\
\hline American Brands & $87 / 05 / 11$ & South Africa & $\begin{array}{l}\text { "...(the firm is)...ending company's presence in } \\
\text { South Africa..." }\end{array}$ & $\mathrm{C}$ \\
\hline Norton Co. & $87 / 03 / 04$ & South Africa & $\begin{array}{l}\text { "...will continue to provide technical support and } \\
\text { allow use of Norton's trademark..." }\end{array}$ & $\mathrm{P}$ \\
\hline McGraw Hill & $87 / 02 / 27$ & South Africa & "...will end all operations in South Africa..." & $\mathrm{C}$ \\
\hline IBM & $86 / 10 / 22$ & South Africa & $\begin{array}{l}\text { "...will continue to supply products to the South } \\
\text { African operation..." }\end{array}$ & $\mathrm{P}$ \\
\hline ITT & $69 / 10 / 30$ & Peru & $\begin{array}{l}\text { "...The (selloff) accord also provides for a } \\
\text { continuation of the telephone expansion program in } \\
\text { China. ITT also agreed to invest } \$ 8.2 \text { Million in } \\
\text { luxury hotels and telephones..." }\end{array}$ & $\mathrm{P}$ \\
\hline Grace and Co. & $69 / 06 / 26$ & Peru & $\begin{array}{l}\text { "...The expropriation will not affect its industrial } \\
\text { operation in paper and chemicals..." }\end{array}$ & $\mathrm{P}$ \\
\hline Cerro Corp. & $69 / 06 / 26$ & Peru & $\begin{array}{l}\text { "...The expropriation of agricultural operations will } \\
\text { not affect its (Cerro's) industrial and mining } \\
\text { operations in any way..." }\end{array}$ & $\mathrm{P}$ \\
\hline Reynolds & $70 / 05 / 22$ & Guyana & $\begin{array}{l}\text { "...Reynolds does not think that the government is } \\
\text { seeking a controlling interest..." }\end{array}$ & $\mathrm{P}$ \\
\hline Anaconda & $71 / 08 / 30$ & Mexico & "...Anaconda will keep 49\%..." & $\mathrm{P}$ \\
\hline Gulf Oil & $75 / 05 / 14$ & Peru & "...announced cessation of all Gulf Oil operations..." & $\mathrm{C}$ \\
\hline IBM & $78 / 06 / 27$ & Nigeria & $\begin{array}{l}\text { "...IBM is pulling out of Nigeria because of } \\
\text { government law against } 100 \% \text { (foreign) } \\
\text { ownership..." }\end{array}$ & $\mathrm{C}$ \\
\hline Newmont Mining & $70 / 11 / 13$ & Algeria & $\begin{array}{l}\text { "...government nationalization of Algerian } \\
\text { properties (of Newmont Mining)..." }\end{array}$ & $\mathrm{C}$ \\
\hline Coca Cola & $77 / 11 / 16$ & India & $\begin{array}{l}\text { "...Coca Cola ceased Indian operations on India's } \\
\text { request to disclose formula or cease operations..." }\end{array}$ & $\mathrm{C}$ \\
\hline
\end{tabular}




\section{Table IV}

\section{Abnormal Returns for Complete and Partial Foreign Asset Transfers of U.S. Corporations}

A. Daily Average Abnormal Returns (AARs) for Firms with Complete and Partial Asset Transfers, the \% of Positive AARs for Both Samples, the Z-values of the Daily Mean Difference of AARs Between Firms with Complete and Partial Assets Transfers for the Event Period -5 Trading Days to +5 Trading Days Around the Initial Announcement (Day Zero) of Foreign Asset Transfers; 1965-1988.

\begin{tabular}{|c|c|c|c|c|c|}
\hline \multirow[b]{2}{*}{ Day } & \multicolumn{2}{|c|}{$\begin{array}{c}\text { Average Abnormal Returns, } \\
\text { AAR, (\%) }\end{array}$} & \multicolumn{2}{|c|}{ Positive AAR (\%) } & \multirow[b]{2}{*}{$\begin{array}{c}\text { Z-difference: } \\
\text { AAR }_{\text {Complete }} \\
\text { - } \mathbf{A} \mathbf{A} \mathbf{R}_{\text {Partial }} \\
\end{array}$} \\
\hline & $\begin{array}{c}\text { Complete } \\
\text { Asset } \\
\text { Transfer } \\
\text { Subsample } \\
(\mathbf{N}=41) \\
\end{array}$ & $\begin{array}{c}\text { Partial Asset } \\
\text { Transfer } \\
\text { Subsample } \\
\quad(\mathrm{N}=43)\end{array}$ & $\begin{array}{c}\text { Complete Asset } \\
\text { Transfer Subsample }\end{array}$ & $\begin{array}{c}\text { Partial Asset Transfer } \\
\text { Subsample }\end{array}$ & \\
\hline-5 & -0.1363 & 0.3148 & 51.2 & 53.5 & -0.60 \\
\hline-4 & 0.3667 & 0.2624 & 51.2 & 51.2 & 0.86 \\
\hline-3 & -0.3488 & -0.2031 & 29.3 & 51.2 & $-1.75^{*}$ \\
\hline-2 & -0.1043 & 0.0978 & 36.6 & 51.2 & -0.01 \\
\hline-1 & 0.1939 & $-0.7112 * *$ & 61.0 & 37.2 & $1.96^{* *}$ \\
\hline 0 & -0.1548 & $-0.4208 * *$ & 43.9 & 34.9 & 0.98 \\
\hline 1 & -0.0240 & -0.2839 & 53.7 & 53.5 & 0.49 \\
\hline 2 & -0.0425 & $0.8118^{*}$ & 51.2 & 51.2 & -1.55 \\
\hline 3 & 0.0046 & 0.1286 & 48.8 & 34.9 & 0.16 \\
\hline 4 & 0.2063 & $-0.5936 * *$ & 53.7 & 32.6 & $2.14^{* *}$ \\
\hline 5 & -0.0961 & -0.3127 & 46.3 & 48.8 & 0.41 \\
\hline
\end{tabular}

B. $\quad$ Cumulative Average Abnormal Returns (CAARs) for firms with Complete and Partial Asset Transfers, the Zvalues for the Mean Difference of CAARs Between Firms with Complete and Partial Asset Transfers, for Several Window Intervals Around the Two-Day Announcement Period $(-1,0)$ of Foreign Asset Transfers; 1965-1988.

\begin{tabular}{c|c|c|c}
\hline $\begin{array}{c}\text { Trading } \\
\text { Interval }\end{array}$ & $\begin{array}{c}\text { Firms with Complete Asset } \\
\text { Transfers (N=41) }\end{array}$ & $\begin{array}{c}\text { Firms with Partial Asset Transfers } \\
(\mathbf{N = 4 3})\end{array}$ & $\begin{array}{c}\text { Z-difference } \\
\text { CAAR }_{\text {Complete }}-\mathbf{C A A R}_{\text {Partial }}\end{array}$ \\
\hline$[-5$ to 5] & -0.1316 & -0.9100 & 0.80 \\
{$[-3$ to 0] } & -0.4139 & $-1.2374^{* *}$ & 0.58 \\
{$[-2$ to 2$]$} & -0.1281 & -0.5064 & 0.83 \\
{$[-2$ to 0$]$} & -0.0651 & $-1.0343^{* *}$ & $1.69^{*}$ \\
{$[-1$ to 0$]$} & 0.0391 & $-1.1320^{* * *}$ & $2.07^{* *}$ \\
{$[-1$ to 1$]$} & 0.0187 & $-1.4160^{* * *}$ & $1.97^{* *}$ \\
{$[0$ to 5] } & -0.1029 & -0.6706 & 1.08 \\
\hline
\end{tabular}

Notes: (1) Day 0 is the first announcement date associated with the selloff as reported in the Wall Street Journal. (2) '***' $\left(' * * ', *^{\prime}\right)$ denotes significance at the $\leq 0.01(0.05,0.10)$ level. 
Table V

Firm Characteristics of U.S. MNCs Involved in Forced Foreign Asset Transfers; 1965-1988

\begin{tabular}{|c|c|c|c|c|c|c|c|c|c|}
\hline \multirow{2}{*}{$\begin{array}{c}\text { Firm Characteristics (in } \\
\text { year prior to divestiture } \\
\text { Announcement) }\end{array}$} & \multicolumn{4}{|c|}{ Complete Asset Transfers } & \multicolumn{4}{|c|}{ Partial Asset Transfers } & \multirow{2}{*}{$\begin{array}{c}\text { t-difference in } \\
\text { Means } \\
\text { (Complete - } \\
\text { Partial) } \\
\end{array}$} \\
\hline & $\begin{array}{c}\text { Number of } \\
\text { Obs. }\end{array}$ & Mean & Median & Range & $\begin{array}{c}\text { Number of } \\
\text { Obs. }\end{array}$ & Mean & Median & Range & \\
\hline $\begin{array}{l}\text { Research and Development } \\
\text { R\&D Expense to Total Assets } \\
\text { (TA) Ratio }\end{array}$ & 40 & $1.65 \%$ & $0.52 \%$ & $8.97 \%$ & 40 & $1.34 \%$ & $0.42 \%$ & $6.57 \%$ & 0.64 \\
\hline $\begin{array}{l}\text { Advertising Expense (AE) to } \\
\text { Total Assets Ratio }\end{array}$ & 40 & $2.36 \%$ & $0.0 \%$ & $18.47 \%$ & 40 & $0.51 \%$ & $0.0 \%$ & $9.13 \%$ & $2.46 * *$ \\
\hline$(\mathrm{R} \& \mathrm{D}+\mathrm{AE}) / \mathrm{TA}$ & 40 & $4.02 \%$ & $1.44 \%$ & $18.47 \%$ & 40 & $1.85 \%$ & $0.56 \%$ & $9.30 \%$ & $2.50 * *$ \\
\hline $\begin{array}{l}\text { Foreign Sales to Total Sales } \\
\text { Ratio }\end{array}$ & 20 & $36.8 \%$ & $38.0 \%$ & $57.47 \%$ & 31 & $32.0 \%$ & $33.0 \%$ & $54.5 \%$ & 1.02 \\
\hline Assets Size (Millions) & 39 & $9,842.55$ & $3,650.6$ & $69,031.58$ & 39 & $11,885.65$ & $2,796.36$ & $196,081.7$ & -0.36 \\
\hline $\begin{array}{l}\text { Relative Foreign Involvement } \\
\text { (RFI) }\end{array}$ & 26 & $1.36 \%$ & $1.00 \%$ & $10.95 \%$ & 25 & $3.41 \%$ & $1.12 \%$ & $23.67 \%$ & $-1.61 *$ \\
\hline Cash Flow/Sales & 30 & 0.1195 & 0.1057 & 0.2366 & 23 & 0.0932 & 0.1035 & 0.2988 & 1.32 \\
\hline Sales/Total Assets & 39 & 1.0683 & 1.0543 & 2.4815 & 39 & 1.0043 & 0.9510 & 2.0848 & 0.60 \\
\hline Working Capital/Total Sales & 38 & 0.1499 & 0.1430 & 0.5021 & 38 & 0.1692 & 0.1699 & 0.4927 & -0.82 \\
\hline $\begin{array}{l}\text { Long Term } \\
\text { Debt/Shareholders Equity }\end{array}$ & 38 & 0.3437 & 0.2738 & 1.2785 & 38 & 0.5192 & 0.2697 & 3.7659 & -1.31 \\
\hline Foreign Taxes/Total Taxes & 27 & 0.1934 & 0.5207 & 8.2586 & 23 & 0.2678 & 0.3012 & 5.0226 & -0.20 \\
\hline Total Employees (Millions) & 37 & 0.1016 & 0.0584 & 0.8080 & 37 & 0.1079 & 0.0510 & 0.8334 & -0.17 \\
\hline
\end{tabular}

Notes: '**, $*$ ' denotes significance at the $(5,10 \%)$ level respectively.

All Data are obtained form COMPUSTAT Annual Industrial Files. Data definitions are as follows:

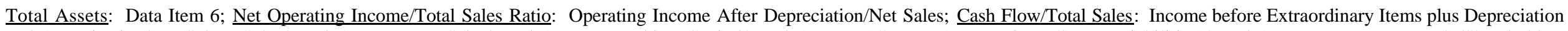

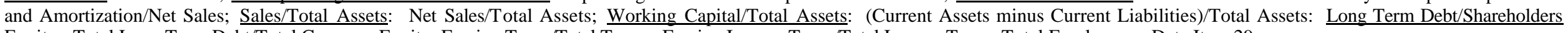
Equity: Total Long Term Debt/Total Common Equity; Foreign Taxes/Total Taxes: Foreign Income Taxes/Total Income Taxes; Total Employees: Data Item 29.

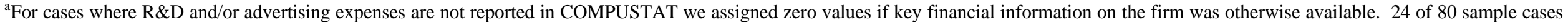
received such treatment. The conclusions remain unchanged when we exclude these observations from the sample (see Morck and Yeung (1992) for similar treatment).

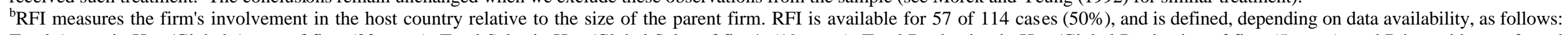

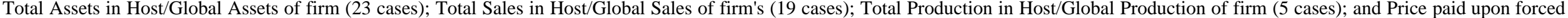

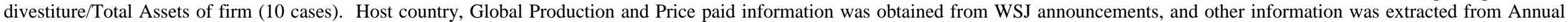
COMPUSTAT Tapes. 


\section{Table VI}

\section{Cross-Section Regression Analysis}

Estimated Coefficients and t-statistics (in parentheses) from Cross-Sectional Regressions of the Two-Day (-1,0) Announcement Period Standardized Cumulative Abnormal Returns, SCAR 1,0 for U.S. MNCs at the Announcement of Forced Foreign Asset Transfers on the Type of AssetTransfers (PCD), the Degree of Foreign Involvement (DFI), the Intangible Assets (INA) of the Divesting Firms, the Relative Foreign Involvement (RFI) of the MNC in the host country and Several Control Variables; 1965-1988

$\operatorname{SCAR}(-1,0)=a+b_{1} \mathbf{P C D}_{i}+b_{2} I N A_{i}+b_{3} R_{F I}+b_{4} S_{S A F}+e_{t}$

\begin{tabular}{|c|c|c|c|c|c|c|c|}
\hline Regression & $\mathbf{a}$ & $b_{1}$ & $\mathbf{b}_{2}$ & $\mathbf{b}_{3}$ & $\mathbf{b}_{4}$ & $\begin{array}{l}\text { No. of } \\
\text { observations }\end{array}$ & Adjusted $\mathbf{R}^{2}$ \\
\hline 1 & $\begin{array}{l}-0.4948 \\
(-3.26)^{* * *}\end{array}$ & $\begin{array}{l}0.4529 \\
(2.27)\end{array}$ & & & & 84 & 0.0475 \\
\hline 2 & $\begin{array}{l}-0.4062 \\
(-3.83)^{* * *}\end{array}$ & & $\begin{array}{l}7.1946^{* * *} \\
(3.13)^{2 *}\end{array}$ & & & $102^{\mathrm{b}}$ & 0.0800 \\
\hline 3 & $\begin{array}{l}-0.1094 \\
(-0.75)\end{array}$ & & & $\begin{array}{l}-7.5148 \\
(-2.58)^{* *}\end{array}$ & & 55 & 0.0952 \\
\hline 4 & $\begin{array}{l}-0.3450 \\
(-3.48)\end{array}$ & & & & $\begin{array}{l}0.4010^{*} \\
(1.99)^{*}\end{array}$ & 107 & 0.0272 \\
\hline 5 & $\begin{array}{l}-0.5129 \\
(-3.40)^{* * *}\end{array}$ & $\begin{array}{l}0.3142 \\
(1.49)_{-}\end{array}$ & $\begin{array}{l}5.6680^{* *} \\
(2.15)^{2}\end{array}$ & & & 79 & 0.0860 \\
\hline 6 & $\begin{array}{l}-0.3390 \\
(-1.54)\end{array}$ & $\begin{array}{l}0.3963 \\
(1.43)\end{array}$ & & $\begin{array}{l}-6.3739 \\
(-2.05)^{*}\end{array}$ & & 51 & 0.1072 \\
\hline 7 & $\begin{array}{l}-0.4028 \\
(-2.21)^{* *}\end{array}$ & & $\begin{array}{l}8.3309 \\
(2.63)^{* *}\end{array}$ & $\begin{array}{l}-5.8318{ }^{* *} \\
(-2.05)^{*}\end{array}$ & & 54 & 0.1901 \\
\hline 8 & $\begin{array}{l}-0.4104^{* * *} \\
(-3.78)^{* *}\end{array}$ & & $\begin{array}{l}6.9451^{* *} \\
(2.53)^{2}\end{array}$ & & $\begin{array}{l}0.0399 \\
(0.17)\end{array}$ & 102 & 0.0710 \\
\hline
\end{tabular}

${ }^{a} \mathrm{SCAR}$ is the standardized cumulative abnormal return during the announcement period of day -1 to day 0 .

PCD is a zero-one dummy variable that takes on the value of 1 when a firm completely transfers its assets its involvement in a foreign country and 0 when it undertakes partial asset transfer (i.e., maintaining a fraction of its previous operating structure in a foreign country).

INA is the Research and Development plus Advertising Expenses to Total Assets Ratio in the year prior to the divestiture announcement.

RFI measures the seller's involvement in the host country relative to the size of the parent firm.

SAF is assigned a value of 1 if the target country is South Africa, and a value of 0 otherwise.

${ }^{\mathrm{b}}$ Complete information on R\&D and Advertising Expenses were available only for 30 cases in the sample. Equation (3) was reestimated using only these cases. The coefficient of the intangible assets variable (INA) retained its positive sign and magnitude (i.e., $\left.9.7619(2.998)^{* * *}\right)$. Alternatively, for an additional 38 observations, R\&D information, but no advertising expense information was available. For these cases, treating the missing cases as zero and reestimating regression (3) produced similar results. The intangible assets coefficient was found to be 8.850 (with a t-value of 3.992) and highly significant. For an additional 5 cases, R\&D information was missing, but advertising expense information was not.

Estimation of regression (3) treating the missing $R \& D$ values as zero again produced similar results. Finally, reestimation of the other regressions using only the cases of nonmissing data on $R \& D$ and advertising expenses produced similar results, and the estimation from these runs are available upon request.

'***' $(' * * ', ' * ')$ denotes significance at the $\leq 0.01(0.05,0.10)$ level. 


\section{Table VII}

\section{Regression Results Following Foreign Country-Specific News}

Estimated Coefficients and t-statistics (in parentheses) from Cross-Sectional Regressions of the Two-Day (-1,0) Firm-specific Announcement Period Standardized Abnormal Returns, $\mathrm{SCAR}_{-1,0}^{\mathrm{F}}$ for U.S. MNCs at the Announcement of Forced Foreign Asset Transfers on the Two-Day (-1,0) Country-specific Announcement Period Standardized Abnormal Returns, SCAR ${ }_{-1,0}^{C}$ Prior to the Asset-Transfer Announcement, the Type of Asset Transfer (PCD), the Intangible Assets (INA) of the Divesting Firms and the Relative Foreign Involvement (RFI) of the MNC in the host country; 1965-1988

\begin{tabular}{|c|c|c|c|c|c|c|c|}
\hline Reg. & $\alpha_{0}$ & $\alpha_{1}$ & $\alpha_{2}$ & $\alpha_{3}$ & $\alpha_{4}$ & $\begin{array}{c}\begin{array}{c}\text { No of } \\
\text { Observations }\end{array} \\
\end{array}$ & Adj. $\mathbf{R}^{2}$ \\
\hline 1 & $\begin{array}{r}-0.4175 \\
(-2.94)^{* * *}\end{array}$ & $\begin{array}{l}0.0857 \\
(1.516)\end{array}$ & $\begin{array}{r}0.6091 \\
(2.032)^{* *}\end{array}$ & & & 82 & 0.0543 \\
\hline 2 & $\begin{array}{r}-0.3650 \\
(-3.404)^{* *}\end{array}$ & $\begin{array}{r}0.1552 \\
(2.174)^{* *}\end{array}$ & & $\begin{array}{r}6.7758 \\
(2.986)^{* * *}\end{array}$ & & 100 & 0.1099 \\
\hline 3 & $\begin{array}{l}-0.1912 \\
(-1.299)\end{array}$ & $\begin{array}{r}0.1683 \\
(1.619)\end{array}$ & & & $\begin{array}{l}-2.0066 \\
(-1.010)\end{array}$ & 55 & 0.0310 \\
\hline 4 & $\begin{array}{l}-0.4994 \\
(-2.804)\end{array}$ & $\begin{array}{r}0.1640 \\
(1.671)\end{array}$ & & $\begin{array}{r}9.1097 \\
(2.877)^{* * *}\end{array}$ & $\begin{array}{l}-0.9802 \\
(-0.513)\end{array}$ & 55 & 0.1511 \\
\hline 5 & $\begin{array}{r}-0.6667 \\
(-3.095) * * *\end{array}$ & $\begin{array}{r}0.1750 \\
(1.715)^{*}\end{array}$ & $\begin{array}{r}0.4066 \\
(1.498)\end{array}$ & $\begin{array}{r}7.8102 \\
(2.324) * *\end{array}$ & $\begin{array}{l}-0.8144 \\
(-1.414)\end{array}$ & 50 & 0.1632 \\
\hline
\end{tabular}

Notes:

'***'('**', $*$ ') denotes significance at the $\leq 0.01(0.05,0.10)$ level. 
Table VIII

Performance Changes Based on EPS Around Forced Foreign Asset-Transfer Announcements: 1965-1988

A. All Firms

\begin{tabular}{|c|c|c|c|c|c|}
\hline Year & $\begin{array}{c}\text { Number of Firms } \\
\text { (Raw, Industry } \\
\text { Adjusted) }\end{array}$ & Mean (\%) & Median (\%) & Mean (\%) & Median (\%) \\
\hline-2 & $102(98)$ & -0.247 & $0.089 * *$ & $-0.754 *$ & $-0.134 * *$ \\
\hline-1 & $102(98)$ & -0.057 & $0.233 * * *$ & -0.359 & -0.084 \\
\hline+1 & $99(95)$ & -0.464 & 0.095 & -0.897 & $-0.544 * *$ \\
\hline+2 & $92(92)$ & 0.366 & $0.380 * * *$ & -0.734 & -0.081 \\
\hline
\end{tabular}

B. Firms with High Levels of Intangible Assets

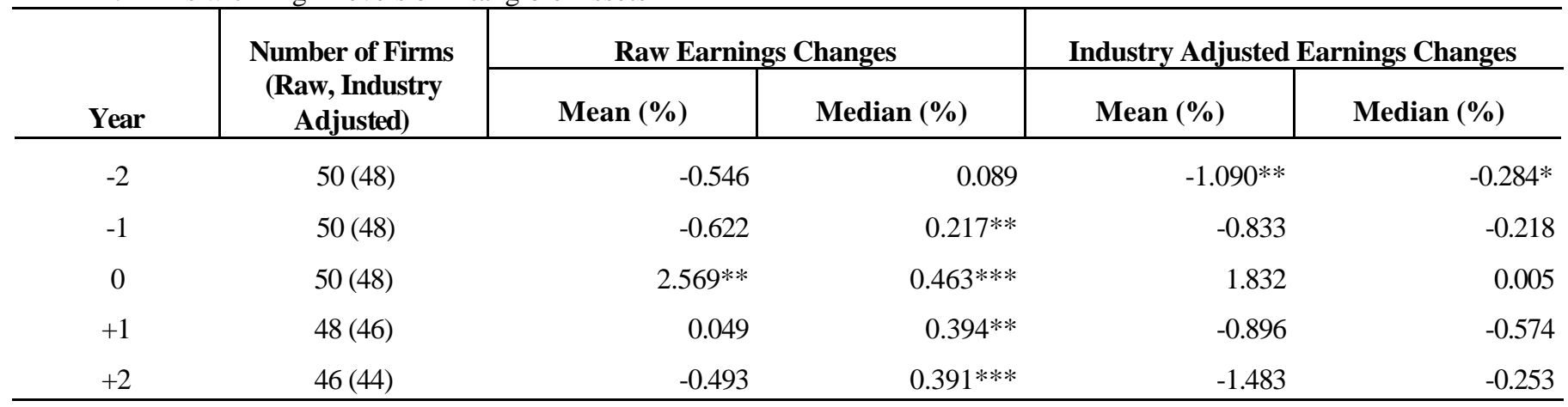

C. Firms with Low Levels of Intangible Assets

\begin{tabular}{|c|c|c|c|c|c|}
\hline Year & $\begin{array}{c}\text { Number of Firms } \\
\text { (Raw, Industry } \\
\text { Adjusted) }\end{array}$ & Mean (\%) & Median (\%) & Mean (\%) & Median (\%) \\
\hline-2 & $52(50)$ & 0.041 & 0.075 & -0.430 & $-0.106^{*}$ \\
\hline-1 & $52(50)$ & 0.487 & $0.458 * * *$ & 0.144 & -0.069 \\
\hline+1 & $51(49)$ & -0.947 & -0.113 & -0.899 & $-0.309 *$ \\
\hline+2 & $50(48)$ & 1.156 & $0.311 * * *$ & -0.048 & -0.052 \\
\hline
\end{tabular}

Notes:

(1) Firms are classified into the High/Low intangible Assets categories as follows: if the firm's R\&D plus Advertising Expense Ratio in the year prior to the selloff is higher than (or equal to) the sample median, then we place the observation into the High category, and Low otherwise.

(2) Change in earnings per share before extraordinary items and discontinued operations are standardized by firm's stock price one fiscal year prior to selloff announcement.

(3) Year 0 is the first fiscal year following the selloff announcement.

(4) Sample sizes are dictated by data availability on Compustat II annual industrial files.

(5) Industry adjusted earnings changes for each firm represent standardized earnings changes less the median standardized earnings changes for all firms in the industry.

(6) '***' ('**','*') denotes significance at the $\leq 0.01(0.05,0.10)$ level. 